\title{
Effect of 50\% and maximal inspired oxygen concentrations on respiratory variables in isoflurane-anesthetized horses
}

\author{
John AE Hubbell ${ }^{1 *}$, Turi K Aarnes ${ }^{1}$, Richard M Bednarski ${ }^{1}$, Phillip Lerche ${ }^{1}$ and William W Muir ${ }^{2}$
}

\begin{abstract}
Background: The purpose of this study was to compare the effects of 0.5 fraction of inspired oxygen $\left(\mathrm{FiO}_{2}\right)$ and $>0.95 \mathrm{FiO}_{2}$ on pulmonary gas exchange, shunt fraction and oxygen delivery $\left(\mathrm{DO}_{2}\right)$ in dorsally recumbent horses during inhalant anesthesia. The use of $0.5 \mathrm{FiO}_{2}$ has the potential to reduce absorption atelectasis (compared to maximal $\mathrm{FiO}_{2}$ ) and augment alveolar oxygen $\left(\mathrm{O}_{2}\right.$ ) tensions (compared to ambient air) thereby improving gas exchange and $\mathrm{DO}_{2}$. Our hypothesis was that $0.5 \mathrm{FiO}_{2}$ would reduce ventilation-perfusion mismatching and increase the fraction of pulmonary blood flow that is oxygenated, thus improving arterial oxygen content and $\mathrm{DO}_{2}$.

Results: Arterial partial pressures of $\mathrm{O}_{2}$ were significantly higher than preanesthetic levels at all times during anesthesia in the $>0.95 \mathrm{FiO}_{2}$ group. Arterial partial pressures of $\mathrm{O}_{2}$ did not change from preanesthetic levels in the $0.5 \mathrm{FiO}_{2}$ group but were significantly lower than in the $>0.95 \mathrm{FiO}_{2}$ group from 15 to 90 min of anesthesia. Alveolar to arterial $\mathrm{O}_{2}$ tension difference was increased significantly in both groups during anesthesia compared to preanesthetic values. The alveolar to arterial $\mathrm{O}_{2}$ tension difference was significantly higher at all times in the $>0.95 \mathrm{FiO}_{2}$ group compared to the $0.5 \mathrm{FiO}_{2}$ group. Oxygen delivery did not change from preanesthetic values in either group during anesthesia but was significantly lower than preanesthetic values 10 min after anesthesia in the $0.5 \mathrm{FiO}_{2}$ group. Shunt fraction increased in both groups during anesthesia attaining statistical significance at varying times. Shunt fraction was significantly increased in both groups 10 min after anesthesia but was not different between groups. Alveolar dead space ventilation increased after $3 \mathrm{hr}$ of anesthesia in both groups.

Conclusions: Reducing $\mathrm{FiO}_{2}$ did not change alveolar dead space ventilation or shunt fraction in dorsally recumbent, mechanically ventilated horses during $3 \mathrm{hr}$ of isoflurane anesthesia. Reducing $\mathrm{FiO}_{2}$ in dorsally recumbent isoflurane anesthetized horses does not improve oxygenation or oxygen delivery.
\end{abstract}

\section{Background}

Maximal $\mathrm{FiO}_{2}$ values (>95\%) have been administered to horses to maintain or improve the arterial partial pressure of oxygen $\left(\mathrm{PaO}_{2}\right)$ and tissue oxygenation since the advent of inhalant anesthesia [1]. Maximal $\mathrm{FiO}_{2}$ concentrations are used in the belief that their use optimizes arterial $\mathrm{O}_{2}$ content $\left(\mathrm{CaO}_{2}\right)$ and $\mathrm{O}_{2}$ delivery $\left(\mathrm{DO}_{2}\right)$ to tissues providing cardiac output $(\mathrm{Q})$ is maintained [2]. Lower than expected (subnormal) $\mathrm{PaO}_{2}$ values are frequently encountered during equine inhalant anesthesia despite the use of maximal

\footnotetext{
* Correspondence: hubbell.2@osu.edu

'Deparment of Veterinary Clinical Sciences, College of Veterinary Medicine, The Ohio State University, 601 Vernon L. Tharp St., Columbus, OH 43210, USA

Full list of author information is available at the end of the article
}

$\mathrm{FiO}_{2}$ [3-6]. Subnormal $\mathrm{PaO}_{2}$ values usually develop during the first 30 to $90 \mathrm{~min}$ of anesthesia, continue for the duration of anesthesia, and resolve within $60 \mathrm{~min}$ of recovery to standing [4]. The 5 mechanisms producing subnormal $\mathrm{PaO}_{2}$ values are decreased $\mathrm{FiO}_{2}$, diffusion impairment, vascular shunting (true shunt), hypoventilation, and ventilation-perfusion mismatching (pseudo shunt) [4]. Decreased $\mathrm{FiO}_{2}$, diffusion impairment, and vascular shunts are unlikely to contribute to subnormal $\mathrm{PaO}_{2}$ during inhalation anesthesia in normal horses. Hypoventilation [arterial partial pressures of carbon dioxide $\left(\mathrm{PaCO}_{2}\right)>5.92 \mathrm{kPa}$ ( $45 \mathrm{~mm} \mathrm{Hg})]$ is a common occurrence during equine anesthesia because virtually all anesthetic drugs cause respiratory depression. Hypoventilation is easily corrected by mechanical ventilation [7]. The use of mechanical
C Biomed Central

() 2011 Hubbell et al; licensee BioMed Central Ltd. This is an Open Access article distributed under the terms of the Creative Commons Attribution License (http://creativecommons.org/licenses/by/2.0), which permits unrestricted use, distribution, and reproduction in any medium, provided the original work is properly cited. 
ventilators, mechanical ventilation and increased $\mathrm{FiO}_{2}$ probably reduces the incidence of subnormal $\mathrm{PaO}_{2}$ values however a significant number of horses continue to experience subnormal $\mathrm{PaO}_{2}$ despite normocapnia and increased $\mathrm{FiO}_{2}[2,5,6]$.

The major cause of subnormal $\mathrm{PaO}_{2}$ values in anesthetized horses is ventilation-perfusion mismatching within the lung parenchyma [8]. Functional residual capacity and residual volume are reduced in recumbent horses during inhalant anesthesia [3]. The distribution of ventilation is shifted to non-dependent areas of lung and altered by changes in diaphragmatic function and mechanical ventilation [9-13]. The shifting of the distribution of lung ventilation uncouples ventilation and perfusion because lung perfusion remains primarily caudaldorsal regardless of body posture [14-16]. Ventilationperfusion mismatching is exacerbated by atelectasis because collapsed alveoli continue to be perfused with little or no gas exchange. The two primary causes of atelectasis are compression (from overlying abdominal contents) and absorption (collapse due to absorption of the alveolar gas). Compression atelectasis is more pronounced in dorsally recumbent horses compared to other species due to its long, sloping diaphragm [17]. The development of compression atelectasis can be partially offset or delayed by initiating mechanical ventilation early during the anesthetic period but predicted $\mathrm{PaO}_{2}$ values are not always achieved [2]. Ventilatory recruitment maneuvers including the use of positive end expiratory pressure (PEEP) have been investigated in horses, however improvements are inconsistent and only occur when PEEP values that compromise $Q$ are employed $[12,18,19]$.

The relationship between $\mathrm{PaO}_{2}$ and hemoglobin saturation varies with blood temperature, $\mathrm{pH}$ and intracellular factors $[13,20]$. Although equine hemoglobin is more than $90 \%$ saturated at $\mathrm{PaO}_{2}$ values greater than $9.2 \mathrm{kPa}(70 \mathrm{~mm} \mathrm{Hg})$, there is rapid desaturation at values below $7.9 \mathrm{kPa}(60 \mathrm{~mm} \mathrm{Hg})$ [13]. One author has provided data from anesthetized horses demonstrating that $\mathrm{DO}_{2}$ decreases when $\mathrm{PaO}_{2}$ decreases, and that $\mathrm{PaO}_{2}$ values less than $5.6 \mathrm{kPa}(50 \mathrm{~mm} \mathrm{Hg})$ are associated with decreases in venous partial pressure of oxygen $\left(\mathrm{PvO}_{2}\right)$, an indicator of the adequacy of $\mathrm{DO}_{2}$ [21].

The recognition that atelectasis contributes to ventilation-perfusion mismatching, intrapulmonary shunt and subnormal $\mathrm{PaO}_{2}$ values has raised questions about the use of maximal $\mathrm{FiO}_{2}$ [22,23]. Absorption atelectasis is exacerbated by administering maximal $\mathrm{FiO}_{2}$ because $\mathrm{O}_{2}$ is more readily absorbed than other, less soluble, gases such as nitrogen. Further, studies in humans suggest that the use of maximal $\mathrm{FiO}_{2}$ promotes alveolar damage, reduces cardiac index, and increases peripheral vascular resistance $[24,25]$. The use of $0.5 \mathrm{FiO}_{2}$ could reduce absorption atelectasis and augment alveolar $\mathrm{O}_{2}$ tensions (compared to ambient air) thereby improving gas exchange and $\mathrm{DO}_{2}$. The purpose of this study was to compare the effects of $0.5 \mathrm{FiO}_{2}$ and $>0.95 \% \mathrm{FiO}_{2}$ on pulmonary gas exchange, shunt fraction $(\mathrm{Qs} / \mathrm{Qt})$ and $\mathrm{DO}_{2}$ in dorsally recumbent horses during inhalant anesthesia. Our hypothesis was that $0.5 \mathrm{FiO}_{2}$ would reduce ventilation-perfusion mismatching and increase the fraction of pulmonary blood flow that is oxygenated, thus improving $\mathrm{CaO}_{2}$ and $\mathrm{DO}_{2}$.

\section{Results}

All horses completed all phases of the experiment. Initial flow rates for the $0.5 \mathrm{FiO}_{2}$ group were $3 \mathrm{~L} /$ min of $\mathrm{O}_{2}$ and $6 \mathrm{~L} / \mathrm{min}$ of air. Flow rates required to maintain $0.5 \mathrm{FiO}_{2}$ when the total flow rate was set at $9 \mathrm{~mL} / \mathrm{kg}$ bwt/min ranged from 1.8 to $3 \mathrm{~L} / \mathrm{min}$ for $\mathrm{O}_{2}$ and 3 to 4 $\mathrm{L} / \mathrm{min}$ for air. All horses were administered dobutamine during each trial (dose range 0.5-1 $\mu \mathrm{g} / \mathrm{kg} / \mathrm{min}$ ). One horse developed atrial fibrillation 30 min after induction of anesthesia during the second procedure $\left(>0.95 \mathrm{FiO}_{2}\right)$. Atrial fibrillation continued throughout anesthesia and an electrocardiogram confirmed normal sinus rhythm 1 hr after the horse stood. Blood pressures and heart rates in this horse were similar to other horses in this treatment group and ranged from 30 to $36 \mathrm{bpm}$ prior to the onset of atrial fibrillation and from 35 to $56 \mathrm{bpm}$ after the onset of atrial fibrillation.

There were no changes or differences in right atrial pressure (RAP), mean pulmonary artery pressure (MPAP), cardiac output (Q), cardiac index (CI), or systemic vascular resistance (SVR) over time or between groups (Table 1). Dobutamine-augmented arterial blood pressures were significantly decreased from preanesthetic values in both groups from 15 to 180 min after induction to anesthesia. Arterial blood pressure was significantly higher than preanesthetic values $30 \mathrm{~min}$ after standing in the $0.5 \mathrm{FiO}_{2}$ group but only mean arterial blood pressure (MABP) was significantly higher in the $>0.95 \mathrm{FiO}_{2}$ group at this interval. There were no differences between groups. Respiratory rate was controlled at a rate of 4 - 5 breaths/min during anesthesia. Respiratory rate was significantly decreased compared to preanesthetic levels $10 \mathrm{~min}$ after anesthesia in both groups.

Arterial partial pressures of $\mathrm{O}_{2}$ were significantly higher than preanesthetic values at all times during anesthesia in the $>0.95 \mathrm{FiO}_{2}$ group (Table 2). Arterial partial pressures of $\mathrm{O}_{2}$ did not change from preanesthetic values in the $0.5 \mathrm{FiO}_{2}$ group and were significantly lower than the $>0.95 \mathrm{FiO}_{2}$ group at the 15, 30, 60 , and 90 min measurement intervals (Table 2). Arterial hemoglobin saturations were not different from preanesthetic levels or between groups at any point during anesthesia in either group but were significantly lower 
Table 1 Hemodynamic and patient variables from isoflurane-anesthetized horses $(n=5)$ breathing $50 \%$ or maximal oxygen concentrations

\begin{tabular}{|c|c|c|c|c|c|c|c|c|c|c|c|}
\hline Parameter & $\mathrm{FiO2}$ & $-5 \min$ & $15 \mathrm{~min}$ & $30 \mathrm{~min}$ & $60 \mathrm{~min}$ & $90 \mathrm{~min}$ & $120 \mathrm{~min}$ & $150 \mathrm{~min}$ & $180 \min$ & $+10 \min$ & Stand $+30 \mathrm{~min}$ \\
\hline \multirow{2}{*}{$\begin{array}{l}\text { HR } \\
\text { (beats/min) }\end{array}$} & $50 \%$ & $35 \pm 2$ & $32 \pm 1$ & $39 \pm 2$ & $40 \pm 3$ & $46 \pm 3$ & $43 \pm 2$ & $39 \pm 3$ & $39 \pm 3$ & $38 \pm 4$ & $38 \pm 2$ \\
\hline & $>95 \%$ & $42 \pm 6$ & $35 \pm 3$ & $37 \pm 3$ & $39 \pm 5$ & $39 \pm 3$ & $42 \pm 3$ & $41 \pm 4$ & $43 \pm 4$ & $34 \pm 4$ & $45 \pm 5$ \\
\hline \multirow{2}{*}{$\begin{array}{l}\text { RR } \\
\text { (breaths/min) }\end{array}$} & $50 \%$ & $26 \pm 3$ & $6 \pm 0^{\mathrm{a}}$ & $5 \pm 0^{a}$ & $5 \pm 0^{\mathrm{a}}$ & $4 \pm 0^{a}$ & $4 \pm 0^{a}$ & $4 \pm 0^{\mathrm{a}}$ & $4 \pm 0^{a}$ & $12 \pm 1^{a}$ & $20 \pm 5$ \\
\hline & $>95 \%$ & $27 \pm 5$ & $6 \pm 0^{a}$ & $5 \pm 0^{a}$ & $5 \pm 0^{a}$ & $5 \pm 0^{a}$ & $5 \pm 0^{a}$ & $5 \pm 0^{a}$ & $5 \pm 0^{a}$ & $12 \pm 4^{\mathrm{a}}$ & $17 \pm 2$ \\
\hline \multirow[t]{2}{*}{$\mathrm{PIP}\left(\mathrm{cmH}_{2} \mathrm{O}\right)$} & $50 \%$ & -—- & $29 \pm 4$ & $30 \pm 3$ & $31 \pm 3$ & $31 \pm 3$ & $32 \pm 3$ & $32 \pm 3$ & $33 \pm 3$ & -—— & -—— \\
\hline & $>95 \%$ & -—- & $30 \pm 4$ & $29 \pm 3$ & $31 \pm 2$ & $32 \pm 3$ & $31 \pm 3$ & $32 \pm 3$ & $31 \pm 3$ & -—— & -—— \\
\hline \multirow[t]{2}{*}{ EtCO2 (kPa) } & $50 \%$ & -— & $4.18 \pm 0.21$ & $4.08 \pm 0.13$ & $4.18 \pm 0.13$ & $4.42 \pm 0.18$ & $4.21 \pm 0.04$ & $4.05 \pm 0.10$ & $3.97 \pm 0.11$ & -— & -— \\
\hline & $>95 \%$ & -—- & $3.92 \pm 0.33$ & $4.32 \pm 0.30$ & $4.47 \pm 0.62$ & $4.34 \pm 0.12$ & $4.21 \pm 0.09$ & $4.03 \pm 0.12$ & $3.82 \pm 0.12$ & -—- & $-—-$ \\
\hline \multirow[t]{2}{*}{ SABP (mmHg) } & $50 \%$ & $143 \pm 9$ & $109 \pm 6^{a}$ & $88 \pm 5^{a}$ & $107 \pm 4^{a}$ & $106 \pm 3^{a}$ & $105 \pm 2^{a}$ & $100 \pm 1^{a}$ & $104 \pm 2^{a}$ & $128 \pm 5$ & $176 \pm 8^{a}$ \\
\hline & $>95 \%$ & $147 \pm 7$ & $106 \pm 8^{a}$ & $95 \pm 4^{\mathrm{a}}$ & $103 \pm 6^{a}$ & $103 \pm 7^{a}$ & $104 \pm 6^{a}$ & $105 \pm 4^{a}$ & $102 \pm 5^{a}$ & $129 \pm 7$ & $172 \pm 10$ \\
\hline \multirow[t]{2}{*}{ MABP (mmHg) } & $50 \%$ & $110 \pm 3$ & $82 \pm 5^{a}$ & $66 \pm 4^{\mathrm{a}}$ & $80 \pm 2^{\mathrm{a}}$ & $85 \pm 1^{a}$ & $84 \pm 2^{a}$ & $84 \pm 3^{a}$ & $85 \pm 1^{a}$ & $109 \pm 4$ & $138 \pm 7^{a}$ \\
\hline & $>95 \%$ & $112 \pm 6$ & $82 \pm 9^{a}$ & $69 \pm 3^{a}$ & $79 \pm 5^{a}$ & $80 \pm 4^{a}$ & $81 \pm 4^{a}$ & $84 \pm 4^{a}$ & $82 \pm 2^{a}$ & $106 \pm 4$ & $136 \pm 6^{\mathrm{a}}$ \\
\hline \multirow[t]{2}{*}{ DABP (mmHg) } & $50 \%$ & $87 \pm 5$ & $69 \pm 4$ & $54 \pm 3^{a}$ & $68 \pm 2$ & $72 \pm 3$ & $73 \pm 3$ & $71 \pm 4$ & $76 \pm 2$ & $96 \pm 3$ & $123 \pm 11^{a}$ \\
\hline & $>95 \%$ & $93 \pm 6$ & $69 \pm 8$ & $58 \pm 4^{a}$ & $66 \pm 4^{a}$ & $67 \pm 3^{\mathrm{a}}$ & $72 \pm 4$ & $73 \pm 4$ & $70 \pm 3$ & $97 \pm 4$ & $115 \pm 6$ \\
\hline \multirow[t]{2}{*}{ MRAP (mmHg) } & $50 \%$ & $14 \pm 3$ & $6 \pm 2$ & $9 \pm 1$ & $10 \pm 2$ & $9 \pm 2$ & $12 \pm 1$ & $12 \pm 1$ & $13 \pm 2$ & $24 \pm 1$ & $15 \pm 3$ \\
\hline & $>95 \%$ & $13 \pm 2$ & $10 \pm 2$ & $13 \pm 1$ & $12 \pm 2$ & $11 \pm 2$ & $12 \pm 3$ & $14 \pm 3$ & $14 \pm 3$ & $21 \pm 4$ & $14 \pm 3$ \\
\hline \multirow[t]{2}{*}{ MPAP (mmHg) } & $50 \%$ & $30 \pm 4$ & $14 \pm 1$ & $17 \pm 0$ & $20 \pm 2$ & $23 \pm 2$ & $24 \pm 3$ & $24 \pm 2$ & $23 \pm 2$ & $36 \pm 2$ & $32 \pm 3$ \\
\hline & $>95 \%$ & $31 \pm 2$ & $21 \pm 5$ & $23 \pm 4$ & $26 \pm 5$ & $26 \pm 5$ & $26 \pm 5$ & $26 \pm 5$ & $26 \pm 5$ & $34 \pm 5$ & $34 \pm 4$ \\
\hline \multirow[t]{2}{*}{ Q (L/min) } & $50 \%$ & $34.2 \pm 5.6$ & $25.4 \pm 2.8$ & $28.1 \pm 3.4$ & $31.5 \pm 2.8$ & $32.9 \pm 3.8$ & $25.2 \pm 3.3$ & $23.3 \pm 2.4$ & $22.7 \pm 1.5$ & $19.9 \pm 1.4$ & $36.5 \pm 3.6$ \\
\hline & $>95 \%$ & $34.2 \pm 3.6$ & $22.5 \pm 1.1$ & $24.2 \pm 1.5$ & $30.1 \pm 1.9$ & $26.1 \pm 3.6$ & $25.2 \pm 3.1$ & $21.1 \pm 0.9$ & $21.3 \pm 0.9$ & $21.8 \pm 1.5$ & $40.2 \pm 3.9$ \\
\hline \multirow[t]{2}{*}{ Cl (L/kg bwt/min) } & $50 \%$ & $0.056 \pm 0.010$ & $0.041 \pm 0.004$ & $0.045 \pm 0.005$ & $0.051 \pm 0.005$ & $0.053 \pm 0.005$ & $0.041 \pm 0.005$ & $0.038 \pm 0.004$ & $0.037 \pm 0.0002$ & $0.032 \pm 0.002$ & $0.059 \pm 0.006$ \\
\hline & $>95 \%$ & $0.056 \pm 0.005$ & $0.037 \pm 0.001$ & $0.040 \pm 0.003$ & $0.049 \pm 0.003$ & $0.043 \pm 0.006$ & $0.041 \pm 0.005$ & $0.035 \pm 0.001$ & $0.035 \pm 0.001$ & $0.036 \pm 0.002$ & $0.066 \pm 0.007$ \\
\hline \multirow[t]{2}{*}{ SVR (dyn sec $\mathrm{cm}^{-5}$ ) } & $50 \%$ & $248 \pm 33$ & $249 \pm 34$ & $172 \pm 23$ & $182 \pm 13$ & $195 \pm 21$ & $245 \pm 33$ & $258 \pm 26$ & $261 \pm 22$ & $347 \pm 17$ & $282 \pm 36$ \\
\hline & $>95 \%$ & $234 \pm 13$ & $256 \pm 26$ & $190 \pm 25$ & $182 \pm 15$ & $227 \pm 35$ & $227 \pm 21$ & $268 \pm 14$ & $256 \pm 13$ & $318 \pm 24$ & $251 \pm 22$ \\
\hline
\end{tabular}

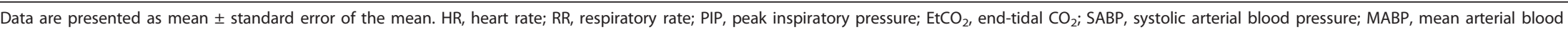
pressure; DABP, diastolic arterial blood pressure; MRAP, mean right atrial pressure; MPAP, mean pulmonary artery pressure; $Q$, cardiac output; Cl, cardiac index; SVR, systemic vascular resistance. Time points: -5 , 15 , $30,60,90,120,150$, and 180 represent min prior to and after induction of anesthesia; +10 min represents 10 min after disconnection from the anesthesia machine; and Stand +30 min represents 30 min after the horses stood in recovery.

a Within a treatment, value is significantly different than the -5 min value for this variable. 
Table 2 Blood variables from isoflurane-anesthetized horses $(n=5)$ breathing $50 \%$ or maximal oxygen concentrations

\begin{tabular}{|c|c|c|c|c|c|c|c|c|c|c|c|}
\hline Parameter & $\mathrm{FiO2}$ & $-5 \min$ & $15 \mathrm{~min}$ & $30 \mathrm{~min}$ & $60 \mathrm{~min}$ & $90 \mathrm{~min}$ & $120 \mathrm{~min}$ & $150 \mathrm{~min}$ & $180 \mathrm{~min}$ & $+10 \mathrm{~min}$ & Stand $+30 \mathrm{~min}$ \\
\hline \multirow[t]{2}{*}{$\mathrm{pHa}$} & $50 \%$ & $7.446 \pm 0.016$ & $7.448 \pm 0.014$ & $7.461 \pm 0.011$ & $7.429 \pm 0.008$ & $7.409 \pm 0.014$ & $7.414 \pm 0.016$ & $7.424 \pm 0.012$ & $7.412 \pm 0.016$ & $7.375 \pm 0.022$ & $7.425 \pm 0.011$ \\
\hline & $>95 \%$ & $7.428 \pm 0.013$ & $7.461 \pm 0.031$ & $7.437 \pm 0.032$ & $7.424 \pm 0.027$ & $7.431 \pm 0.021$ & $7.424 \pm 0.018$ & $7.432 \pm 0.014$ & $7.441 \pm 0.017$ & $7.386 \pm 0.031$ & $7.438 \pm 0.005$ \\
\hline \multirow[t]{2}{*}{$\mathrm{PaO}_{2}(\mathrm{kPa})$} & $50 \%$ & $12.06 \pm 0.92$ & $12.15 \pm 1.24^{b}$ & $12.55 \pm 0.98^{b}$ & $13.73 \pm 01.16^{\mathrm{b}}$ & $13.48 \pm 1.39^{b}$ & $12.55 \pm 1.54$ & $10.89 \pm 1.43$ & $10.29 \pm 1.48$ & $5.60 \pm 0.24$ & $12.00 \pm 0.35$ \\
\hline & $>95 \%$ & $12.07 \pm 0.53$ & $36.03 \pm 4.02^{a, b}$ & $32.13 \pm 4.78^{\mathrm{a}, \mathrm{b}}$ & $36.47 \pm 5.93^{a, b}$ & $34.18 \pm 5.24^{a, b}$ & $31.37 \pm 6.32^{\mathrm{a}}$ & $29.20 \pm 6.12$ & $28.61 \pm 6.34$ & $5.92 \pm 0.37$ & $10.39 \pm 1.07$ \\
\hline \multirow[t]{2}{*}{ Arterial $\mathrm{Hb}(\mathrm{g} / \mathrm{dL})$} & $50 \%$ & $13.2 \pm 1.7$ & $12.4 \pm 0.4$ & $12.0 \pm 0.5$ & $14.1 \pm 0.2$ & $13.8 \pm 0.2$ & $13.5 \pm 0.5$ & $13.0 \pm 0.7$ & $12.8 \pm 0.5$ & $12.6 \pm 0.3$ & $11.8 \pm 0.5$ \\
\hline & $>95 \%$ & $12.0 \pm 0.5$ & $11.9 \pm 0.4$ & $13.0 \pm 0.6$ & $13.7 \pm 0.8$ & $13.7 \pm 0.3$ & $13.6 \pm 0.4$ & $13.7 \pm 0.7$ & $13.3 \pm 0.7$ & $12.2 \pm 0.6$ & $11.5 \pm 0.3$ \\
\hline \multirow[t]{2}{*}{$\mathrm{PaCO}_{2}(\mathrm{kPa})$} & $50 \%$ & $4.84 \pm 0.38$ & $4.79 \pm 0.30$ & $4.63 \pm 0.20$ & $5.08 \pm 0.08$ & $5.53 \pm 0.36$ & $5.26 \pm 0.25$ & $5.11 \pm 0.10$ & $5.52 \pm 0.32$ & $6.76 \pm 0.53^{a}$ & $5.59 \pm 0.23$ \\
\hline & $>95 \%$ & $5.36 \pm 0.23$ & $4.57 \pm 0.45$ & $5.25 \pm 0.37$ & $5.37 \pm 0.38$ & $5.39 \pm 0.31$ & $5.51 \pm 0.16$ & $5.57 \pm 0.18$ & $5.42 \pm 0.26$ & $6.70 \pm 0.76$ & $5.76 \pm 0.20$ \\
\hline \multirow[t]{2}{*}{$\mathrm{PaHCO}_{3}(\mathrm{mmol} / \mathrm{L})$} & $50 \%$ & $26 \pm 1$ & $26 \pm 0$ & $26 \pm 1$ & $26 \pm 0$ & $26 \pm 1$ & $25 \pm 1$ & $25 \pm 1$ & $26 \pm 1$ & $27 \pm 1$ & $27 \pm 1$ \\
\hline & $>95 \%$ & $27 \pm 1$ & $25 \pm 1$ & $27 \pm 1$ & $26 \pm 1$ & $27 \pm 0$ & $27 \pm 1$ & $28 \pm 1$ & $28 \pm 1$ & $28 \pm 0$ & $29 \pm 1$ \\
\hline \multirow[t]{2}{*}{$\mathrm{SaO}_{2}(\%)$} & $50 \%$ & $96.3 \pm 0.5$ & $95.8 \pm 0.8$ & $96.4 \pm 0.4$ & $96.4 \pm 0.5$ & $96.2 \pm 0.4$ & $95.6 \pm 0.9$ & $94.7 \pm 1.3$ & $93.4 \pm 1.8$ & $81.5 \pm 1.7^{\mathrm{a}}$ & $96.5 \pm 0.2$ \\
\hline & $>95 \%$ & $96.8 \pm 0.3$ & $97.8 \pm 0.1$ & $97.6 \pm 0.1$ & $97.6 \pm 0.2$ & $97.6 \pm 0.1$ & $97.5 \pm 0.2$ & $97.4 \pm 0.3$ & $97.0 \pm 0.7$ & $84.0 \pm 2.2^{\mathrm{a}}$ & $95.1 \pm 0.9$ \\
\hline \multirow[t]{2}{*}{$\mathrm{pHv}$} & $50 \%$ & $7.402 \pm 0.010$ & $7.418 \pm 0.011$ & $7.433 \pm 0.008$ & $7.408 \pm 0.008$ & $7.400 \pm 0.011$ & $7.398 \pm 0.011$ & $7.397 \pm 0.013$ & $7.392 \pm 0.012$ & $7.347 \pm 0.015$ & $7.387 \pm 0.008$ \\
\hline & $>95 \%$ & $7.399 \pm 0.006$ & $7.422 \pm 0.027$ & $7.408 \pm 0.027$ & $7.401 \pm 0.024$ & $7.397 \pm 0.020$ & $7.398 \pm 0.016$ & $7.402 \pm 0.015$ & $7.407 \pm 0.016$ & $7.352 \pm 0.019$ & $7.397 \pm 0.004$ \\
\hline \multirow[t]{2}{*}{$\mathrm{PvO}_{2}(\mathrm{kPa})$} & $50 \%$ & $4.44 \pm 0.41$ & $4.44 \pm 0.09$ & $4.61 \pm 0.12$ & $5.55 \pm 0.22$ & $5.64 \pm 0.14$ & $5.34 \pm 0.27$ & $4.95 \pm 0.33$ & $4.85 \pm 0.29$ & $3.72 \pm 0.18$ & $3.74 \pm 0.21$ \\
\hline & $>95 \%$ & $4.11 \pm 0.10$ & $4.96 \pm 0.11$ & $5.08 \pm 0.16$ & $5.88 \pm 0.34^{a}$ & $5.79 \pm 0.43^{\mathrm{a}}$ & $5.71 \pm 0.48^{\mathrm{a}}$ & $5.43 \pm 0.35$ & $5.32 \pm 0.34$ & $3.73 \pm 0.19$ & $3.59 \pm 0.26$ \\
\hline \multirow[t]{2}{*}{ VLactate (mmol/L) } & $50 \%$ & $0.5 \pm 0$ & $1.1 \pm 0.1$ & $1.2 \pm 0.1$ & $1.3 \pm 0.1$ & $1.4 \pm 0.1^{\mathrm{a}}$ & $1.4 \pm 0.1^{\mathrm{a}}$ & $1.5 \pm 0.1^{\mathrm{a}}$ & $1.5 \pm 0.1^{a}$ & $1.4 \pm 0.1^{a}$ & $1.1 \pm 0.2$ \\
\hline & $>95 \%$ & $0.5 \pm 0.1$ & $1.2 \pm 0.1$ & $1.4 \pm 0.1$ & $1.4 \pm 0.1^{\mathrm{a}}$ & $1.3 \pm 0.1$ & $1.4 \pm 0.1$ & $1.5 \pm 0.1^{\mathrm{a}}$ & $1.5 \pm 0.1^{\mathrm{a}}$ & $1.4 \pm 0.1^{\mathrm{a}}$ & $1.2 \pm 0.5$ \\
\hline
\end{tabular}

Data are presented as mean \pm standard error of the mean. $\mathrm{pHa}$, arterial $\mathrm{pH} ; \mathrm{PaO}_{2}$, arterial partial pressure of oxygen; Arterial $\mathrm{Hb}$, arterial hemoglobin; $\mathrm{PaCO}_{2}$, arterial partial pressure of carbon dioxide; $\mathrm{PaHCO}$, arterial bicarbonate; $\mathrm{SaO}_{2}$, arterial oxygen saturation; $\mathrm{pHv}$, venous $\mathrm{pH} \mathrm{PvO}_{2}$, venous partial pressure of oxygen; vLactate, venous lactate. Time points: -5, 15, 30, 60, 90, 120, 150, and 180 represent min prior to and after induction of anesthesia; $+10 \mathrm{~min}$ represents $10 \mathrm{~min}$ after disconnection from the anesthesia machine; and Stand +30 min represents 30 min after the horses stood in recovery.

Within a treatment, value is significantly different than the -5 min value for this variable.

b Within this time point, value is significantly different than other treatment 
than preanesthetic levels at the 10 min postanesthetic measurement interval in both groups. Venous partial pressure of oxygen was increased compared to baseline from 60 to $120 \mathrm{~min}$ in the $>0.95 \mathrm{FiO}_{2}$ group but there were no differences between groups. Venous lactate concentrations were increased compared to preanesthetic concentrations from 90 to $180 \mathrm{~min}$ during anesthesia and $10 \mathrm{~min}$ after anesthesia in the $0.5 \mathrm{FiO}_{2}$ group and at 60, 150, and $180 \mathrm{~min}$ during anesthesia and $10 \mathrm{~min}$ after anesthesia in $>0.95 \mathrm{FiO}_{2}$ group. There were no differences in venous lactate concentrations between groups (Table 2).

Arterial $\mathrm{O}_{2}$ content $\left(\mathrm{CaO}_{2}\right)$, venous $\mathrm{O}_{2}$ content $\left(\mathrm{CvO}_{2}\right)$, and oxygen extraction ratio $\left(\mathrm{O}_{2} \mathrm{ER}\right)$ did not change during the experiment (Table 3$)$. Oxygen consumption $\left(\mathrm{VO}_{2}\right)$ decreased after induction to anesthesia, becoming significant from 60 to $180 \mathrm{~min}$ in the $0.5 \mathrm{FiO}_{2}$ group and at 15 min in the $>0.95 \mathrm{FiO}_{2}$ group. Oxygen consumption was not different between groups. Alveolar to arterial $\mathrm{O}_{2}$ tension differences $\left(\mathrm{P}_{(\mathrm{A}-\mathrm{a})} \mathrm{O}_{2}\right)$ were significantly increased during anesthesia compared to preanesthetic values in both groups and tension differences in the $>0.95 \mathrm{FiO}_{2}$ group were significantly higher than in $0.5 \mathrm{FiO}_{2}$ group at all measurement intervals. Oxygen delivery did not change from preanesthetic levels during anesthesia in either group but was significantly lower than preanesthetic levels $10 \mathrm{~min}$ after anesthesia in the $0.5 \mathrm{FiO}_{2}$ group. Shunt fraction increased in both groups during anesthesia and was significant at $60,90,150$, and $180 \mathrm{~min}$ in the $0.5 \mathrm{FiO}_{2}$ group and from 15 to $150 \mathrm{~min}$ in the $>0.95 \mathrm{FiO}_{2}$ group. Shunt fraction was significantly increased in both groups $10 \mathrm{~min}$ after anesthesia. Shunt fraction was not different between groups at any time point. Alveolar dead space ventilation $\left(V_{d} / V_{t}\right)$ was increased after $3 \mathrm{hr}$ of anesthesia in both groups compared to $15 \mathrm{~min}$ after induction.

Horses stood at $96+/-13 \mathrm{~min}$ and $91+/-10 \mathrm{~min}$ in the $>0.95 \mathrm{FiO}_{2}$ and $0.5 \mathrm{FiO}_{2}$ groups, respectively (Table 4). Times to first movement, extubation, first attempt to sternal recumbency, sternal recumbency, first attempt to stand, and standing were not different between groups (Table 4). Median number of attempts to stand was 1 and median recovery score was 3 in both groups.

\section{Discussion}

The use of $0.5 \mathrm{FiO}_{2}$ in dorsally-recumbent isofluraneanesthetized horses did not reduce Qs/Qt or Vd/Vt compared to $>0.95 \mathrm{FiO}_{2}$. Arterial partial pressures of $\mathrm{O}_{2}$ and $\mathrm{P}_{(\mathrm{A}-\mathrm{a})} \mathrm{O}_{2}$ were higher in horses breathing $>0.95 \mathrm{FiO}_{2}$ but $\mathrm{DO}_{2}$ was not different between groups during $3 \mathrm{hr}$ of anesthesia or after anesthesia. Reduction of $\mathrm{FiO}_{2}$ from $>95 \%$ to $50 \%$ did not improve pulmonary gas exchange or oxygenation.

The results of this study support the hypothesis that the development of Qs/Qt mismatching from compression atelectasis is the most likely cause of impaired arterial oxygenation during inhalant anesthesia in the horse [8]. Shunt fraction, $\mathrm{P}_{(\mathrm{A}-\mathrm{a})} \mathrm{O}_{2}$, and $\mathrm{Vd} / \mathrm{Vt}$ increased in both groups after induction to anesthesia in our study. Our results differ from two previous reports that found a greater Qs/Qt in horses that breathed $>0.95 \mathrm{FiO}_{2}$ compared to horses that breathed air during intravenous anesthesia [8] and an increase in $\mathrm{Vd} / \mathrm{Vt}$ when $>0.85 \mathrm{FiO}_{2}$ was compared to $0.35 \mathrm{FiO}_{2}$ in spontaneously breathing, halothane-anesthetized horses [26]. In agreement with our results, the administration of varying helium-oxygen mixtures did not change Qs/Qt but resulted in progressive increases in $\mathrm{P}_{(\mathrm{A}-\mathrm{a})} \mathrm{O}_{2}$ and $\mathrm{PaO}_{2}$ as $\mathrm{FiO}_{2}$ increased [27]. Differences between our results and those of others may be due to the $\mathrm{FiO}_{2}$ selected ( 0.5 versus 0.2 to 0.35 ), the effects of intravenous and different inhalant anesthetics (isoflurane versus no inhalant or halothane), the duration of anesthesia, the mode of ventilation (controlled ventilation versus spontaneous ventilation), or body position (dorsal recumbency versus lateral recumbency). Positive pressure ventilation and inhalant anesthetics alter the distribution of ventilation in the anesthetized horse but most have accepted this limitation of the two techniques in the interest of normalization of $\mathrm{PaCO}_{2}$ and the maintenance of consistent anesthetic depth [9-12]. Body position is a primary determinant of oxygenation in anesthetized horses with dorsal recumbency consistently associated with larger decrements in pulmonary function and gas exchange $[2,9,28,29]$. The cause for the decrements in pulmonary function has classically been attributed to a gravity-dependent shift in blood flow and a shift in ventilation to less dependent lung zones [30]. This description has been challenged by several studies that have demonstrated that only small shifts in blood flow occur in anesthetized horses after changes of body position [15,29,31]. We purposefully selected overweight horses and placed them in dorsal recumbency for an extended period in order to maximize the potential for changes in $\mathrm{FiO}_{2}$ to improve gas exchange and reduce hypoxemia [5,32-34].

Similar to others we confirmed that $>0.95 \mathrm{FiO}_{2}$ is associated with greater $\mathrm{PaO}_{2}$ and $\mathrm{P}_{(\mathrm{A}-\mathrm{a})} \mathrm{O}_{2}$ values than the those produced by 0.2 to $0.5 \mathrm{FiO}_{2}$ and that $\mathrm{CaO}_{2}$ and $\mathrm{DO}_{2}$ may not be markedly different if arterial hemoglobin remains fully saturated [23,26,27]. Step-wise increases in $\mathrm{FiO}_{2}$ to titrate $\mathrm{PaO}_{2}$ and $\mathrm{CaO}_{2}$ have been proposed [27] but such an approach requires multiple gas sources, the ability to determine $\mathrm{FiO}_{2}$ and frequent sampling of arterial blood for arterial blood gas analysis. The differences in $\mathrm{PaO}_{2}$ and $\mathrm{P}_{(\mathrm{A}-\mathrm{a})} \mathrm{O}_{2}$ between the two groups in the face of no difference in calculated Qs/Qt is a function of the sigmoid shape of the oxyhemoglobin saturation curve and highlights the importance of considering both $\mathrm{PaO}_{2}$ and $\mathrm{CaO}_{2}$ when assessing the 
Table 3 Oxygen variables from isoflurane-anesthetized horses $(n=5)$ breathing $50 \%$ or maximal oxygen concentrations

\begin{tabular}{|c|c|c|c|c|c|c|c|c|c|c|c|}
\hline Parameter & $\mathrm{FiO2}$ & $-5 \min$ & $15 \mathrm{~min}$ & $30 \mathrm{~min}$ & $60 \mathrm{~min}$ & $90 \mathrm{~min}$ & $120 \mathrm{~min}$ & $150 \mathrm{~min}$ & $180 \mathrm{~min}$ & $+10 \mathrm{~min}$ & Stand $+30 \mathrm{~min}$ \\
\hline \multirow[t]{2}{*}{$\overline{\mathrm{CaO}_{2}(\mathrm{~mL} / \mathrm{dL})}$} & $50 \%$ & $17.9 \pm 2.1$ & $16.7 \pm 0.5$ & $16.4 \pm 0.7$ & $19.3 \pm 0.3$ & $18.7 \pm 0.3$ & $18.3 \pm 0.7$ & $17.4 \pm 1.1$ & $16.9 \pm 1.0$ & $14.4 \pm 0.4$ & $16.2 \pm 0.6$ \\
\hline & $>95 \%$ & $16.4 \pm 0.7$ & $17.0 \pm 0.5$ & $18.3 \pm 1.0$ & $19.4 \pm 1.2$ & $19.4 \pm 0.6$ & $19.1 \pm 0.7$ & $19.2 \pm 1.1$ & $18.6 \pm 1.2$ & $14.3 \pm 0.8$ & $15.4 \pm 0.6$ \\
\hline \multirow[t]{2}{*}{$\mathrm{CrO}_{2}(\mathrm{~mL} / \mathrm{dL})$} & $50 \%$ & $13.0 \pm 1.7$ & $13.1 \pm 0.6$ & $13.2 \pm 0.5$ & $16.9 \pm 0.6$ & $16.6 \pm 0.3$ & $15.5 \pm 0.9$ & $14.9 \pm 1.5$ & $14.1 \pm 1.3$ & $9.9 \pm 0.7$ & $10.2 \pm 0.7$ \\
\hline & $>95 \%$ & $11.3 \pm 0.5$ & $14.3 \pm 0.5$ & $15.1 \pm 1.0$ & $16.5 \pm 1.4$ & $16.4 \pm 1.2$ & $15.9 \pm 1.3$ & $15.4 \pm 1.3$ & $14.7 \pm 1.3$ & $9.7 \pm 0.8$ & $9.3 \pm 1.2$ \\
\hline \multirow[t]{2}{*}{$\mathrm{O}_{2} \mathrm{ER}(\%)$} & $50 \%$ & $27 \pm 4$ & $22 \pm 2$ & $19 \pm 3$ & $12 \pm 3$ & $11 \pm 1$ & $15 \pm 3$ & $15 \pm 4$ & $17 \pm 3$ & $32 \pm 3$ & $37 \pm 4$ \\
\hline & $>95 \%$ & $31 \pm 1$ & $16 \pm 2$ & $18 \pm 4$ & $15 \pm 3$ & $16 \pm 4$ & $17 \pm 5$ & $20 \pm 3$ & $21 \pm 3$ & $32 \pm 3$ & $40 \pm 6$ \\
\hline \multirow[t]{2}{*}{$\mathrm{VO}_{2}(\mathrm{~mL} / \mathrm{kg} \mathrm{bwt} / \mathrm{min})$} & $50 \%$ & $2.9 \pm 1$ & $1.5 \pm 0.2$ & $1.4 \pm 0.2$ & $1.1 \pm 0.2^{\mathrm{a}}$ & $1.1 \pm 0.1^{\mathrm{a}}$ & $1.0 \pm 0.1^{\mathrm{a}}$ & $0.9 \pm 0.1^{\mathrm{a}}$ & $1.0 \pm 0.1^{\mathrm{a}}$ & $1.4 \pm 0.1$ & $3.5 \pm 0.5$ \\
\hline & $>95 \%$ & $2.8 \pm 0.2$ & $1.0 \pm 0.1^{\mathrm{a}}$ & $1.3 \pm 0.2$ & $1.4 \pm 0.2$ & $1.1 \pm 0.2$ & $1.2 \pm 0.2$ & $1.3 \pm 0.1$ & $1.3 \pm 0.1$ & $1.6 \pm 0.1$ & $4.0 \pm 0.8$ \\
\hline \multirow[t]{2}{*}{$\mathrm{C}(\mathrm{a}-\mathrm{v}) \mathrm{O}_{2}(\mathrm{~mL} / \mathrm{dL})$} & $50 \%$ & $4.87 \pm 0.79$ & $3.61 \pm 0.40$ & $3.20 \pm 0.59$ & $2.34 \pm 0.49$ & $2.12 \pm 0.29$ & $2.77 \pm 0.48$ & $2.53 \pm 0.56$ & $2.73 \pm 0.38$ & $4.52 \pm 0.28$ & $5.93 \pm 0.65$ \\
\hline & $>95 \%$ & $5.12 \pm 0.32$ & $2.75 \pm 0.40$ & $3.28 \pm 0.65$ & $2.86 \pm 0.49$ & $3.00 \pm 0.74$ & $3.18 \pm 0.84$ & $3.75 \pm 0.52$ & $3.83 \pm 0.46$ & $4.61 \pm 0.51$ & $6.08 \pm 0.80$ \\
\hline \multirow[t]{2}{*}{$\mathrm{PaO}_{2}-\mathrm{IO}_{2}$ ratio } & $50 \%$ & $0.64 \pm 0.05$ & $0.27 \pm 0.03^{\mathrm{a}}$ & $0.28 \pm 0.02^{\mathrm{a}}$ & $0.30 \pm 0.02^{\mathrm{a}}$ & $0.29 \pm 0.03^{\mathrm{a}}$ & $0.27 \pm 0.03^{\mathrm{a}}$ & $0.23 \pm 0.03^{\mathrm{a}}$ & $0.22 \pm 0.03^{\mathrm{a}}$ & $0.30 \pm 0.01^{\mathrm{a}}$ & $0.64 \pm 0.02$ \\
\hline & $>95 \%$ & $0.64 \pm 0.03$ & $0.41 \pm 0.05$ & $0.36 \pm 0.05^{a}$ & $0.41 \pm 0.07$ & $0.38 \pm 0.06^{\mathrm{a}}$ & $0.35 \pm 0.07^{\mathrm{a}}$ & $0.32 \pm 0.07^{\mathrm{a}}$ & $0.32 \pm 0.07^{\mathrm{a}}$ & $0.32 \pm 0.02^{\mathrm{a}}$ & $0.55 \pm 0.06$ \\
\hline \multirow[t]{2}{*}{$\mathrm{P}(\mathrm{A}-\mathrm{a}) \mathrm{O}_{2}(\mathrm{kPa})$} & $50 \%$ & $1.84 \pm 1.09$ & $27.51 \pm 2.07^{\mathrm{a}, \mathrm{b}}$ & $27.12 \pm 1.00^{\mathrm{a}, \mathrm{b}}$ & $26.52 \pm 1.05^{\mathrm{a}, \mathrm{b}}$ & $26.79 \pm 1.29^{\mathrm{a}, \mathrm{b}}$ & $27.85 \pm 1.23^{\mathrm{a}, \mathrm{b}}$ & $30.26 \pm 1.60^{\mathrm{a}, \mathrm{b}}$ & $29.81 \pm 1.44^{\mathrm{a}, \mathrm{b}}$ & $5.99 \pm 0.67$ & $0.99 \pm 0.20$ \\
\hline & $>95 \%$ & $1.20 \pm 0.31$ & $45.93 \pm 3.90^{\mathrm{a}, \mathrm{b}}$ & $51.07 \pm 4.51^{\mathrm{a}, \mathrm{b}}$ & $46.77 \pm 5.97^{a, b}$ & $49.22 \pm 5.26^{a, b}$ & $52.08 \pm 6.38^{a, b}$ & $54.36 \pm 6.31^{\mathrm{a}, \mathrm{b}}$ & $55.33 \pm 6.48^{a, b}$ & $5.74 \pm 0.90$ & $2.40 \pm 1.04$ \\
\hline \multirow[t]{2}{*}{$\mathrm{DO}_{2}(\mathrm{~mL} / \mathrm{kg} \mathrm{bwt} / \mathrm{min})$} & $50 \%$ & $10.82 \pm 3.59$ & $6.84 \pm 0.60$ & $7.44 \pm 0.84$ & $9.82 \pm 0.85$ & $9.91 \pm 0.94$ & $7.48 \pm 1.07$ & $6.71 \pm 1.00$ & $6.24 \pm 0.61$ & $4.62 \pm 0.26^{\mathrm{a}}$ & $9.47 \pm 0.78$ \\
\hline & $>95 \%$ & $9.16 \pm 1.00$ & $6.26 \pm 0.24$ & $7.24 \pm 0.49$ & $9.55 \pm 0.89$ & $8.34 \pm 1.19$ & $7.91 \pm 1.03$ & $6.65 \pm 0.50$ & $6.47 \pm 0.44$ & $5.11 \pm 0.41$ & $10.20 \pm 1.19$ \\
\hline \multirow[t]{2}{*}{ Qs/Qt (\%) } & $50 \%$ & $13 \pm 2$ & $28 \pm 4$ & $30 \pm 5$ & $39 \pm 8^{a}$ & $40 \pm 6^{a}$ & $36 \pm 4$ & $40 \pm 4^{\mathrm{a}}$ & $40 \pm 3^{a}$ & $43 \pm 4^{a}$ & $9 \pm 1$ \\
\hline & $>95 \%$ & $9 \pm 1$ & $35 \pm 4^{\mathrm{a}}$ & $36 \pm 6^{a}$ & $36 \pm 4^{a}$ & $38 \pm 5^{a}$ & $37 \pm 4^{\mathrm{a}}$ & $33 \pm 3^{a}$ & $32 \pm 3$ & $38 \pm 5^{a}$ & $12 \pm 2$ \\
\hline \multirow[t]{2}{*}{ Vd/Nt (\%) } & $50 \%$ & -— & $11.9 \pm 4.4$ & $11.7 \pm 1.3$ & $17.6 \pm 1.5$ & $19.4 \pm 2.6$ & $19.4 \pm 3.1$ & $20.5 \pm 2.4$ & $27.2 \pm 3.9^{c}$ & -—- & -— \\
\hline & $>95 \%$ & -— & $13.6 \pm 3.2$ & $17.7 \pm 1.9$ & $16.4 \pm 2.2$ & $18.7 \pm 3.8$ & $23.4 \pm 2.3$ & $27.6 \pm 2.3$ & $29.2 \pm 2.2^{c}$ & & -— \\
\hline
\end{tabular}

Data are presented as mean \pm standard error of the mean. $\mathrm{CaO}_{2}$, arterial oxygen content; $\mathrm{CvO}_{2}$, venous oxygen content; $\mathrm{O}_{2} \mathrm{ER}$, oxygen extraction ratio; $\mathrm{VO}_{2}$, oxygen consumption; $\mathrm{C}(\mathrm{a}-\mathrm{v}) \mathrm{O}_{2}$, oxygen content difference; $\mathrm{PaO}_{2}-\mathrm{OO}_{2}$ ratio, arterial oxygen tension to inspired oxygen tension ratio; $\mathrm{P}(\mathrm{A}-\mathrm{a}) \mathrm{O}_{2}$, alveolar arterial oxygen tension difference; $\mathrm{DO}_{2}$, oxygen delivery; $\mathrm{Qs} / \mathrm{Qt}$, shunt fraction; $\mathrm{Vd} / \mathrm{Vt}$, alveolar dead space. Time points: $-5,15$, $30,60,90,120,150$, and 180 represent min prior to and after induction of anesthesia; $+10 \mathrm{~min}$ represents $10 \mathrm{~min}$ after disconnection from the anesthesia machine; and Stand +30 min represents 30 min after the horses stood in recovery.

a Within a treatment, value is significantly different than the -5 min value for this variable.

$\mathrm{b}$ Within this time point, value is significantly different than other treatment.

c With a treatment, value is significantly different from the $15 \mathrm{~min}$ value for this variable. 


\begin{tabular}{|c|c|c|}
\hline Parameter & $\mathrm{FiO2}>95 \%$ & FiO2 $50 \%$ \\
\hline Time to first movement (min) ${ }^{a}$ & $48 \pm 7$ & $57 \pm 5$ \\
\hline Time to extubation (min) ${ }^{a}$ & $31 \pm 7$ & $34 \pm 6$ \\
\hline $\begin{array}{l}\text { Time to first attempt to sternal } \\
\text { recumbency }(\mathrm{min})^{\mathrm{a}}\end{array}$ & $73 \pm 17$ & $67 \pm 6$ \\
\hline Time to sternal recumbency $(\min )^{a}$ & $88 \pm 13$ & $76 \pm 9$ \\
\hline Time to first attempt to stand (min) & $94 \pm 14$ & $84 \pm 9$ \\
\hline Time to standing $(\min )^{a}$ & $96 \pm 13$ & $91 \pm 10$ \\
\hline Number of attempts to stand ${ }^{b}$ & $1(1-3)$ & $1(1-5)$ \\
\hline Median Recovery Score ${ }^{b}$ & $3(1-4)$ & $3(2-7)$ \\
\hline
\end{tabular}

a Data are presented as mean \pm standard error of the mean.

b Data are presented as median (range).

significance of changes in the ranges of $\mathrm{PaO}_{2}$ and Qs/Qt routinely encountered in the anesthetized horse [35].

The incidence of subnormal $\mathrm{PaO}_{2}$ values and hypoxemia in dorsally recumbent anesthetized horses is a recurring problem during equine anesthesia and has been associated with body shape, body weight, low pulse pressures, emergency case status, and male gender $[5,6,33,34]$. It has been suggested that the application of controlled ventilation immediately after induction to anesthesia is more likely to maintain $\mathrm{PaO}_{2}$ during anesthesia but controlled ventilation may decrease $\mathrm{Q}$ and thus $\mathrm{DO}_{2}[2,21]$. Additional proposed methods of improving oxygenation in anesthetized horses include PEEP, inhalation of aerosolized bronchodilators such as albuterol, selective mechanical ventilation of dependent lung regions and breathing helium-oxygen mixtures $[18,27,36,37]$. Positive end expiratory pressures of at least $10 \mathrm{~cm}$ of water may improve $\mathrm{CaO}_{2}$ without changing Qs/Qt but Q is reduced unless fluids and cardiac inotropes (ex. dobutamine) are administered $[17,18]$. Aerosolized albuterol is reported to increase $\mathrm{PaO}_{2}$ but its effects are inconsistent in the authors' and other's experience regarding efficacy and consistency of effect $[36,38]$. Selective mechanical ventilation combined with selective PEEP consistently increases $\mathrm{DO}_{2}$, however it requires a surgical procedure (tracheostomy) and multiple ventilators [37].

The lowest individual $\mathrm{PaO}_{2}$ measurements in our study ranged from 6.32 to $13.55 \mathrm{kPa}$ (48 to $103 \mathrm{~mm} \mathrm{Hg}$ ) in the $0.5 \mathrm{FiO}_{2}$ group and from 9.21 to $42.1 \mathrm{kPa}$ (70 to $320 \mathrm{~mm} \mathrm{Hg}$ ) in the $>0.95 \mathrm{FiO}_{2}$ group. All horses in 0.5 $\mathrm{FiO}_{2}$ group had $\mathrm{PaO}_{2}$ values below $13.16 \mathrm{kPa}(100 \mathrm{~mm}$ $\mathrm{Hg}$ ) at some time during the anesthetic period and 2 of 5 horses had $\mathrm{PaO}_{2}$ values below $7.89 \mathrm{kPa}(60 \mathrm{~mm} \mathrm{Hg})$. Only one of 5 horses in the $>0.95 \mathrm{FiO}_{2}$ group had a $\mathrm{PaO}_{2}$ below $13.16 \mathrm{kPa}(100 \mathrm{~mm} \mathrm{Hg})$. All horses in both trials had $\mathrm{PaO}_{2}$ values below $7.89 \mathrm{kPa}(60 \mathrm{~mm} \mathrm{Hg})$ ten minutes after discontinuation of anesthesia but $\mathrm{CaO}_{2}$ did not change from preanesthetic levels and was not different between groups at any time suggesting there was no apparent advantage with either technique. Further, recent studies in laterally recumbent isoflurane anesthetized horses have determined that breathing $>0.95 \mathrm{FiO}_{2}$ for 90 min does not affect erythrocyte membrane dynamics or structure, blood viscosity or muscular perfusion and that breathing room air $\left(0.21 \mathrm{FiO}_{2}\right)$ decreases skeletal muscle oxygenation [39].

The results of our study, although limited by a relatively small sample size, are similar and consistent with those of others [23,26]. One of our horses developed atrial fibrillation, which could have influenced the development of V/Q and our results. The range of $\mathrm{HR}$ and $\mathrm{Q}$ for the horse that developed atrial fibrillation was similar in both trials so we do not believe that it affected our results since the development of atrial fibrillation in the absence of cardiac disease, is not necessarily associated with the deterioration of hemodynamics [40]. We did not have the capability of performing the multiple inert gas elimination technique which would have allowed potential differentiation between pulmonary units with low and high V/Q and shunt $[23,41,42]$. Regardless, the ability to more precisely identify V/Q matching and shunt would not have changes our results. Decreases in atelectasis, Qs/Qt, and $\mathrm{P}_{(\mathrm{A}-\mathrm{a})} \mathrm{O}_{2}$ are interesting but unless they result in improvements in $\mathrm{PaO}_{2}$, $\mathrm{CaO}_{2}$, and $\mathrm{DO}_{2}$, their impact is suspect. The risks of inhaling $>0.95 \mathrm{FiO}_{2}$ are well documented in other species [43-45] but we could find no reports of pathology associated with the use of $>0.95 \mathrm{FiO}_{2}$ in horses anesthetized for clinically relevant durations. To the contrary, isoflurane anesthetized horses breathing $>0.95 \% \mathrm{O}_{2}$ for 90 min demonstrated minimal damage from reactive oxygen species and no alterations in muscular perfusion [39]. The use of submaximal $\mathrm{FiO}_{2}$ requires additional equipment and more stringent monitoring thus increasing expense. In the absence of evidence of benefit, the authors do not recommend the use of submaximal 0.5 $\mathrm{FiO}_{2}$ in anesthetized horses.

\section{Conclusion}

The purpose of breathing increased $\mathrm{FiO}_{2}$ during equine anesthesia is to partially offset the loss of the adaptive mechanisms that are initiated by hypoxemia in awake horses such as increases in ventilation, $\mathrm{Q}$ and contraction of the spleen [3]. These mechanisms are obtunded or eliminated during inhalant anesthesia in horses. Our study suggests that decreasing $\mathrm{FiO}_{2}$ to $0.5 \%$ from maximal levels does not improve pulmonary gas exchange or $\mathrm{DO}_{2}$ during inhalant anesthesia in horses. Further studies investigating the benefits of alternative gas mixtures (ex. helium- $\mathrm{O}_{2}$ ) and modes of ventilation in conjunction with changes in $\mathrm{FiO}_{2}$ are warranted. 


\section{Methods}

\section{Horses}

Five mature horses (one Thoroughbred, one Quarterhorse, three Standardbreds; two geldings, three mares) with a mean body weight of $614 \mathrm{~kg}$ bwt (range 578 to $638 \mathrm{~kg}$ bwt) were studied. All horses were maintained on pasture and were judged to be overweight based on subjective evaluations of body conditions and round-bellied appearances [33]. The experimental protocols and procedures were approved by the Institutional Animal Care and Use Committee of The Ohio State University and all horses were treated in compliance with NIH Guidelines for the Care and Use of Laboratory Animals.

\section{Study Design}

The study was conducted as a random-ordered 2-way cross-over. A complete blood count (CBC) and serum biochemistry analysis were performed before and $24 \mathrm{hr}$ after each trial. Food, but not water, was withheld for approximately $12 \mathrm{hr}$ before each trial. All horses underwent two separate 3-hour anesthetic episodes separated by at least 10 days. Each horse was randomly assigned to breathe either $100 \% \mathrm{O}_{2}$ to attain $>0.95 \mathrm{FiO}_{2}$ (Group 1) or $\mathrm{O}_{2}$ blended with medical grade air to attain 0.5 $\mathrm{FiO}_{2}$ (Group 2).

Each horse was confined in a stockade and the hair over the left and right jugular veins was clipped. The skin was surgically prepared for aseptic placement of intravascular and intracardiac catheters. Lidocaine (2\%, $1 \mathrm{ml} /$ site) was injected subcutaneously at two sites over the right jugular vein and one site over the left jugular vein. A 14-gauge Teflon catheter was percutaneously placed in the left jugular vein for administration of anesthetic drugs and isotonic electrolyte solutions $(10 \mathrm{~mL} / \mathrm{kg}$ bwt/hr). Two $8 \mathrm{~F}$ catheter introducers (Catheter introducers CL-07811, Arrow International Inc.) were percutaneously placed in the right jugular vein to facilitate the placement of two catheters: 1) A 7-French specialized thermistor and balloon tipped quadruple lumen catheter (Thermodilution balloon catheter AI-07067, Arrow International Inc.) was positioned so that its distal tip was in the pulmonary artery; and 2) a $110 \mathrm{~cm}$ polyethylene (PE) 240 catheter (Intramedic PE-240 tubing, Becton Dickinson and Company) was positioned so its distal tip was in the right atrium. A 20-gauge 1.25 inch catheter (Surflo catheter, Terumo Medical Corporation) was percutaneously positioned in either transverse facial artery or a 19 gauge through the needle catheter (Intracath, Parke, Davis \& Company) was inserted into a subcutaneously relocated carotid artery. These procedures facilitated the determination of systolic arterial blood pressure (SABP), diastolic arterial blood pressure (DABP), mean arterial blood pressure (MABP), and collection of samples of heparinized blood samples for the determination of arterial $\mathrm{pH}(\mathrm{pHa})$ and blood gas analysis $\left(\mathrm{PaO}_{2} ; \mathrm{PaCO}_{2}\right)$. Heparinized samples of venous blood were anerobically obtained from the pulmonary arterial catheter for determination of venous $\mathrm{pH}$, venous partial pressure of oxygen $\left(\mathrm{PvO}_{2}\right)$, and venous partial pressure of carbon dioxide $\left(\mathrm{PvCO}_{2}\right)$. Proper positioning of all catheters was confirmed by attaching each catheter to a pressure transducer (TruWave Disposable PressureTransducer, Edwards Lifesciences LLC) and visualizing their characteristic pressure waveforms (Datascope Passport Model EL, Datascope Corp.). The scapulohumeral joint was considered the zero pressure reference point. One $\mathrm{mL}$ of iced injectate $\left(5 \%\right.$ dextrose $\left.^{\mathrm{j}}\right)$ solution $/ 15 \mathrm{~kg}$ bwt was rapidly injected via the right atrial catheter (PE 240 catheter) for determination of cardiac output (Q; L/ min) by thermodilution (Cardiomax III, Columbus Instruments). The value for $\mathrm{Q}$ was at each time point was determined by an average of three $Q$ determinations. A base-apex electrocardiogram was used to determine heart rate (HR) and rhythm. The quadruple lumen thermodilution catheter facilitated the determination of $\mathrm{Q}$ and MPAP. The PE 240 catheter was used for the administration of iced injectate for $Q$ determinations and for measurement of MRAP. Respiratory rate (RR) was determined by observing chest excursions in standing horses and movement of the anesthetic machine ventilatory bellows during anesthesia.

Horses were allowed to stand in the stockade undisturbed for $10 \mathrm{~min}$ following catheter placement. Then, baseline heart rate (HR; beats/min), respiratory rate $(R R$, breaths/min), Q (L/min), CI (L/kg bwt/min), SABP (mmHg), MABP (mmHg), DABP (mmHg), MPAP (mmHg), and MRAP (mmHg) were measured. Baseline arterial and venous blood samples were obtained anaerobically for determination of hemoglobin levels, oxygen saturation levels, $\mathrm{pH}$ and blood gas analysis $\left(\mathrm{PaO}_{2}\right.$; $\mathrm{PaCO}_{2} ; \mathrm{PvO}_{2} ; \mathrm{PvCO}_{2}$ ), and lactate determination ( $\mathrm{ABL}$ 725 Radiometer America). Packed cell volumes were determined by centrifugation and total protein levels were determined by refractometry (Clinical refractometer J-351, Jorgensen Laboratories Inc). Horses were moved to a padded induction stall and xylazine $(1.0 \mathrm{mg} /$ $\mathrm{kg}$ bwt, IV) was administered for sedation 5 min after sample collection. Ketamine $(2.2 \mathrm{mg} / \mathrm{kg}$ bwt $)$ and diazepam $(0.1 \mathrm{mg} / \mathrm{kg})$ bwt $)$ were administered as an IV bolus five min after xylazine administration. Once recumbent, horses were positioned in lateral recumbency and a 26 $\mathrm{mm}$ diameter ID orotracheal tube was placed in the trachea. Horses were positioned in dorsal recumbency and appropriately padded. The endotracheal tube was connected to a circle anesthetic machine (Model 2800, Mallard Medical, Inc.) primed with the fresh gas mixture to be tested and 3\% isoflurane (ISO). An initial total fresh gas flow rate of $9 \mathrm{~L} / \mathrm{min}$ was delivered for $15 \mathrm{~min}$ and 
was then reduced to a total of $9 \mathrm{~mL} / \mathrm{kg} \mathrm{bwt} / \mathrm{min}$ for the remainder of the anesthetic period. Anesthesia was maintained at an end-tidal ISO concentration of $2 \%$. Controlled ventilation (initial tidal volume $15 \mathrm{~mL} / \mathrm{kg}$ but, initial respiratory rate 6 breaths/min) was immediately instituted and adjusted to maintain $\mathrm{PaCO}_{2}$ between 40 and $45 \mathrm{mmHg}$. Inspired and expired concentrations of $\mathrm{O}_{2}, \mathrm{CO}_{2}$, and ISO were determined using a sidestream gas analyzer (Poet IQ2 8500Q, Criticare Systems, Inc.). Dobutamine $(1-5 \mu \mathrm{g} / \mathrm{kg} \mathrm{bwt} / \mathrm{min})$ was administered as needed to maintain MABP between 70 and 90 $\mathrm{mm} \mathrm{Hg}$.

Values for HR, SABP, MABP, DABP, MPAP, MRAP, $\mathrm{Q}$, peak inspiratory pressure (PIP; $\mathrm{cmH}_{2} \mathrm{O}$ ), inspired and expired $\mathrm{O}_{2}$ concentrations (\%), inspired and peak expired $\mathrm{CO}_{2}$ concentrations $(\mathrm{mmHg})$, end-tidal ISO concentration (\%) and heparinized samples of arterial and venous blood were anaerobically obtained for determination of $\mathrm{pH}$, blood gases, hemoglobin, and $\mathrm{SO}_{2}$ at $15,30,45,60,90,120,150$, and $180 \mathrm{~min}$ after induction to anesthesia. Tidal volume (V; Liters) was measured using a digital respirometer (Respirometer Model 00295. Anesthesia Associates, Inc.) placed between the endotracheal tube and the breathing circuit. Derived variables calculated from measured data included: systemic vascular resistance (dynes sec $\mathrm{cm}^{-5}$ ), cardiac index (CI; L/kg bwt/min) [46], shunt fraction (Qs/Qt; \%), arterial and venous oxygen content $\left(\mathrm{CaO}_{2}\right.$ and $\mathrm{CvO}_{2}$, respectively; $\mathrm{mL} / \mathrm{dL})$, oxygen consumption $\left(\mathrm{VO}_{2} ; \mathrm{mL} / \mathrm{kg}\right.$ $\mathrm{bwt} / \mathrm{min})$ [46], oxygen delivery $\left(\mathrm{DO}_{2} ; \mathrm{mL} / \mathrm{kg}\right.$ bwt $\left./ \mathrm{min}\right)$ [46], arterial-mixed venous oxygen content difference (C (a-v) $\left.\mathrm{O}_{2} ; \mathrm{mL} / \mathrm{dL}\right)$, oxygen extraction ratio $\left(\mathrm{O}_{2} \mathrm{ER} ; \%\right)$, alveolar dead space $\left(\mathrm{V}_{\mathrm{d}} / \mathrm{V}_{\mathrm{t}} ; \%\right)$, alveolar arterial oxygen tension $\left(\mathrm{P}_{\mathrm{A}} \mathrm{O}_{2} ; \mathrm{kPa}\right)$, alveolar arterial oxygen tension difference $\left(\mathrm{P}_{(\mathrm{A}-\mathrm{a})} \mathrm{O}_{2} ; \mathrm{kPa}\right)$, and arterial partial pressure of oxygen/inspired partial pressure of oxygen ratio $\left(\mathrm{PaO}_{2}\right.$ $\mathrm{IO}_{2}$ ratio). Values were calculated according to the following equations:

$$
\begin{aligned}
& \mathrm{CI}(\mathrm{L} / \mathrm{kg} \text { bwt/min }): \mathrm{Q} / \mathrm{bwt}(\mathrm{kg}) \\
& \text { SVR (dyne sec/cm } \left.{ }^{5}\right):(\text { MABP - RAP) } / Q \times 80 \\
& \mathrm{CaO}_{2}(\mathrm{~mL} / \mathrm{dL}):\left(1.39 \times \mathrm{Hb} \times \mathrm{SaO}_{2}\right)+\left(0.003 \times \mathrm{PaO}_{2}\right)\left(\mathrm{PaO}_{2} \text { in } \mathrm{mmHg}\right) \\
& \mathrm{CvO}_{2}(\mathrm{~mL} / \mathrm{dL}):\left(1.39 \times \mathrm{Hb} \times \mathrm{SvO}_{2}\right)+\left(0.003 \times \mathrm{PvO}_{2}\right)\left(\mathrm{PaCO}_{2} \text { in } \mathrm{mmHg}\right) \\
& \mathrm{O}_{2} \mathrm{ER}(\%): \mathrm{VO}_{2} \times 100 / \mathrm{DO}_{2} \\
& \mathrm{VO}_{2}(\mathrm{~mL} / \mathrm{kg} \text { bwt/min }):\left(\mathrm{CaO}_{2}-\mathrm{CvO}_{2}\right) \times \mathrm{CI} \\
& \mathrm{C}_{(\mathrm{a}-\mathrm{v})} \mathrm{O}_{2}(\mathrm{~mL} / \mathrm{dL}): \mathrm{CaO}_{2}-\mathrm{CvO}_{2}
\end{aligned}
$$

$$
\begin{aligned}
& \mathrm{PaO}_{2}: \text { InspO }{ }_{2} \text { ratio : } \mathrm{PaO}_{2} / \mathrm{InspO}_{2} \\
& \mathrm{PAO}_{2}(\mathrm{kPa}):\left[\mathrm{FiO}_{2} \times\left(\mathrm{PB}-\mathrm{PH}_{2} \mathrm{O}\right)-\left(1.2 \times \mathrm{PaCO}_{2}\right)\right] / 7.6 \\
& \left(\mathrm{P}_{(\mathrm{A}--\mathrm{a})} \mathrm{O}_{2}(\mathrm{kPa}): \mathrm{PAO}_{2}-\mathrm{PaO}_{2}\right. \\
& \mathrm{DO}_{2}(\mathrm{~mL} / \mathrm{kg} \text { bwt } / \mathrm{min}): \mathrm{CI} \times \mathrm{CaO}_{2} \\
& \text { Qs/Qt }(\%):\left(\mathrm{CcO}_{2}-\mathrm{CaO}_{2}\right) /\left(\mathrm{CcO}_{2}-\mathrm{CvO}_{2}\right)
\end{aligned}
$$$$
\text { Vd/Vt (\% ) : } \left.\left[\left(\mathrm{PaCO}_{2}-\mathrm{PETCO}_{2}\right) / \mathrm{PaCO}_{2}\right)\right] \times 100
$$

Horses were transported to a padded recovery stall and positioned in left lateral recumbency after the 180 min collection interval. One breath/min was delivered using a demand valve (Equine Demand Valve Model 5040, JD Medical Distributing) until spontaneous ventilation resumed. Once spontaneous ventilation resumed, xylazine $(0.2 \mathrm{mg} / \mathrm{kg}$ bwt, IV) was administered to provide sedation during recovery. All data was collected 10 min after the anesthetic machine was disconnected and $30 \mathrm{~min}$ after the horse attained a standing position. The times from disconnection from the anesthetic machine to the resumption of spontaneous ventilation, first movement, extubation, first attempt to attain a sternal position, sternal recumbency, first attempt to stand, time to standing, and number of attempts to stand were recorded. The quality of recovery was assessed by at least two independent observers using a 10 point scale: 1. Stands on first attempt with minimal effort, minimal ataxia; 2. Stands on first attempt with minimal to moderate effort, mild ataxia; 3. Stands on first or second attempt with great effort and moderate ataxia. Marked weight shifting once standing; 4. 2-3 attempts to stand, moderate effort, slight weight shifting; 5. 2-3 standing attempts, marked instability once standing; 6. Several weak attempts, marked instability once standing; 7. Several weak attempts, resumes recumbency, minor shifting of weight once standing; 8. Several weak attempts, falls easily or resumes recumbency, minor injury to horse; 9. Several violent attempts, falls or resumes recumbency, minor injury to horse; 10. Several violent attempts, resumes recumbency, major injury to horse or personnel.

\section{Statistical Analysis}

All numerical continuous data are presented as mean \pm standard error of the mean. A 2-way ANOVA with repeated measures was used to analyse for treatment effects and interaction. Tukey-Kramer post-test was performed to identify time and within and between treatment differences. Normally distributed recovery data was analyzed using a 1-tailed paired t-test. Recovery 
score and number of attempts to stand were analyzed using a Wilcoxon signed rank test. A $P<0.05$ was considered significant.

\section{Acknowledgements}

The authors thank Dr. Yukie Ueyama, Carl O'Brien, Amanda English, and Renee Calvin for technical assistance and Drs. Jean Powers and Thomas Wittum for statistical assistance.

\section{Author details}

'Deparment of Veterinary Clinical Sciences, College of Veterinary Medicine, The Ohio State University, 601 Vernon L. Tharp St., Columbus, OH 43210, USA. ${ }^{2} 338$ W. 7th Ave., Columbus, Ohio 43201, USA.

\section{Authors' contributions}

JAEH participated in the design of the study, data collection, statistical analyses, and manuscript preparation. TKA participated in data collection, statistical analyses, and manuscript preparation. RMB participated in the design of the study, data collection, and manuscript preparation. PL participated in data collection and manuscript preparation. WWM participated in the design of the study and manuscript preparation. All authors have read and approved the final manuscript.

\section{Received: 29 December 2010 Accepted: 3 June 2011}

Published: 3 June 2011

\section{References}

1. Hall LW, Gillespie JR, Tyler WS: Alveolar-arterial oxygen tension differences in anaesthetized horses. Brit J Anaes 1968, 40:560-568.

2. Day TK, Gaynor JS, Muir WW, Bednarski RM, Mason DE: Blood gas values during intermittent positive pressure ventilation in 160 anesthetized horses positioned in lateral or dorsal recumbency. Vet Surg 1995, 24:266-276.

3. McDonell WN, Kerr CL: Respiratory system. In Lumb and Jones' Veterinary Anesthesia and Analgesia.. 4 edition. Edited by: Tranquilli WJ, Thurmon JC, Grimm KA. Ames: Blackwell; 2007:117-151.

4. Gillespie JR, Tyler WS, Hall LW: Cardiopulmonary dysfunction in anesthetized, laterally recumbent horses. Am J Vet Res 1969, 30:61-72.

5. Whitehair $\mathrm{K}$, Willits $\mathrm{NH}$ : Predictors of arterial oxygen tension in anesthetized horses: 1,610 cases (1992-1994). J Am Vet Med Assoc 1999, 215:978-981.

6. Hubbell JA, Muir WW, Casey MF: Retrospective study of horses with low arterial $\mathrm{O}_{2}$ tensions. Vet Surg 1986, 5:460.

7. Steffey EP, Wheat JD, Meagher DM, Norrie RD, McKee J, Brown M, Arnold J: Body position and mode of ventilation influences arterial $\mathrm{pH}$, oxygen, and carbon dioxide tensions in halothane-anesthetized horses. Am J Vet Res 1977, 38:379-382

8. Nyman G, Funkquist B, Kvart C, Frostell C, Tokics L, Strandberg A, Lundquist $H$, Lundh B, Brismar B, Hedenstierna G: Atelectasis causes gas exchange impairment in the anaesthetized horse. Equine Vet J 1990, 22:317-324.

9. Sorenson PR, Robinson NE: Postural effects on lung volumes and asynchronous ventilation in anesthetized horses. J Appl Physiol: Respirat Environ Exercise Physiol 1980, 48:97-103.

10. Benson GJ, Manohar M, Kneller SK, Thurmon JC, Steffey EP: Radiographic characterization of diaphragmatic excursion in halothane-anesthetized ponies: Spontaneous and controlled ventilation systems. Am J Vet Res 1982, 43:617-621.

11. Olson LE, Lai-Fook SJ: Pleural liquid pressure measured with rib capsules in anesthetized ponies. J Appl Physiol 1988, 64:102-107.

12. Moens $Y$, Lagerweij E, Gootjes P, Poortman J: Influence of tidal volume and positive end-expiratory pressure on inspiratory gas distribution and gas exchange during mechanical ventilation in horses positioned in lateral recumbency. Am J Vet Res 1998, 59:307-312.

13. Robinson NE: The respiratory system. In Equine Anesthesia Monitoring and Emergency Therapy.. 2 edition. Edited by: Muir WW, Hubbell JAE. St. Louis: Saunders Elsevier; 2009:11-36.
14. Glenny RW, Lamm JE, Albert RK, Robertson HT: Gravity is a minor determinant of pulmonary blood flow distribution. J App Physiol 1991 71:620-629.

15. Jarvis KA, Steffey EP, Tyler WS, Willits N, Woliner M: Pulmonary blood flow distribution in anesthetized ponies. J Appl Physiol 1992, 72:1173-1178.

16. Hlastala MP, Bernard SL, Erickson HH, Fedde MR, Gaughan EM, McMurphy R, Emery MJ, Polissar N, Glenny RW: Pulmonary blood flow distribution in standing horses is not dominated by gravity. J App Physiol 1996, 81:1051-1061.

17. Nyman G, Hedenstierna G: Ventilation-perfusion relationships in the anaesthetized horse. Equine Vet J 1989, 21:274-281.

18. Wilson DV, Soma LR: Cardiopulmonary effects of positive end-expiratory pressure in anesthetized, mechanically ventilated ponies. Am J Vet Res 1990, 51:734-739.

19. Wettstein D, Moens $Y$, Jaeggin-Schumucker N, Bohm SH, Rother HU, Mosing $\mathrm{M}$, Kastner SD, Schatzmann U: Effects of an alveolar recruitment maneuver on cardiovascular and respiratory parameters during total intravenous anesthesia in ponies. Am J Vet Res 2006, 67:152-159.

20. Cambier C, Di Passio N, Clerbauz T, Amory H, Marville V, Detry B, Frans A, Gustin P: Blood oxygen binding in healthy Standardbred horses. Vet J 2005, 169:251-256.

21. Steffey EP, Willits N, Woliner M: Hemodynamic and respiratory responses to variable arterial partial pressure of oxygen in halothane-anesthetized horses during spontaneous and controlled ventilation. Am J Vet Res 1992, 53:1850-1858.

22. Agarwal $A$, Singh PK, Dhiraj S, Pandey $\mathrm{CM}$, Singh $\mathrm{U}$ : Oxygen in air $\left(\mathrm{FiO}_{2}\right.$ 0.4) improves gas exchange in young healthy patients during general anesthesia. Can J Anesth 2002, 49:1040-1043.

23. Marntell S, Nyman G, Hedenstierna G: High inspired oxygen concentrations increase intrapulmonary shunt in anaesthetized horses. Vet Anaes Analg 2005, 32:338-347.

24. Anderson KJ, Harten JM, Booth MG, Kinsella J: The cardiovascular effects of inspired oxygen fraction in anaesthetized patients. Eur J Anaesth 2005, 22:420-425.

25. Barker GF, Manzo ND, Cotich KL, Shone RK, Waxman AB: DNA damage induced by hyperoxia: quantitation and correlation with lung injury. Am J Resp Cell and Mol Biol 2006, 35:277-288.

26. Cuvelliez SG, Eicker SW, McLauchlan C, Brunson DB: Cardiovascular and respiratory effects of inspired oxygen fraction in halothane-anesthetized horses. Am J Vet Res 1990, 51:1226-1231.

27. Staffieri F, Bauquier SH, Moate PJ, Driessen B: Pulmonary gas exchange in anaesthetized horses mechanically ventilated with oxygen or a helium/ oxygen mixture. Equine Vet J 2009, 41:747-752.

28. Schatzmann U, Koehli M, Dudan F, Rohr W, Jones RS: Effect of postural changes on certain circulatory and respiratory values in the horse. Am J Vet Res 1982, 43:1003-1005.

29. Dobson A, Gleed RD, Meyer RE, Stewart BJ: Changes in blood flow distribution in equine lungs induced by anesthesia. Q J Exp Physiol 1985, 70:283-297.

30. West JB: Blood flow and metabolism. In Respiratory Physiology The Essentials.. 8 edition. Edited by: West JB. Baltimore: Lippincott Williams and Wilkins; 2008:35-53.

31. Sinclair SE, McKinney S, Glenny RW, Bernard SL, Hlastala MP: Exercise alters fractal dimension and spatial correlation of pulmonary blood flow. J App/ Physiol 2000, 88:2269-2278.

32. Hall LW: Disturbances of cardiopulmonary function in anaesthetized horses. Equine Vet J 1971, 3:95-98.

33. Moens Y, Lagerweij E, Gootjes P, Poortman J: Distribution of inspired gas to each lung in the anaesthetized horse and influence of body shape. Equine Vet J 1995, 27:110-116.

34. Mansel JC, Clutton RE: The influence of body mass and thoracic dimensions on arterial oxygenation in anaesthetized horses and ponies. Vet Anaes Analg 2008, 35:392-399.

35. Lumb AB: Oxygen. In Nunn's Applied Respiratory Physiology.. 6 edition. Edited by: Lumb AB. Italy: Elsevier Limited; 2005:166-200.

36. Robertson SA, Bailey JE: Aerosolized salbutamol (albuterol) improves $\mathrm{PaO}_{2}$ in hypoxaemic anaesthetized horses- a prospective clinical trial in 81 horses. Vet Anaes Analg 2002, 29:212-218.

37. Nyman G, Frostell C, Hedenstierna G, Funkquist B, Kvart C, Blomqvist H: Selective mechanical ventilation of dependent lung regions in the 
anaesthetized horse in dorsal recumbency. $\mathrm{Br} J$ Anaesth 1987, 59:1027-1034.

38. Gunkel Cl, Valverde A, Robertson SA, Thompson MS, Keoughan CG, Ferrell EA: Treatment for a severe reaction to intravenous administration of diatrozoate in an anesthetized horse. J Am Vet Med Assoc 2004, 224:1143-1146.

39. Portier K, Crouzier D, Guichardant M, Prost M, Debouzy JC, Kirschvink N, Fellmann N, Lekeux P, Coudert J: Effects of high and low inspired fractions of oxygen on horse erythrocyte membrane properties, blood viscosity and muscle oxygenation during anaesthesia. Vet Anaesth Analg 2009, 36:287-98

40. Muir WW, McGuirk SM: Hemodynamics before and after conversion of atrial fibrillation to normal sinus rhythm in horses. J Am Vet Med Assoc 1984, 184:965-970

41. Hedenstierna G, Nyman G, Kvart C, Funkquist B: Ventilation-perfusion relationships in the standing horse: an inert gas elimination study. Equine Vet J 1987, 19:514-519.

42. Marntell $S$, Nyman G, Funkquist $P$, Hedenstierna G: Effects of acepromazine on pulmonary gas exchange and circulation during sedation and dissociative anaesthesia in horses. Vet Anaes Analg 2005, 32:83-93.

43. Crapo JD: Morphological changes in pulmonary oxygen toxicity. Ann Rev Physiol 1986, 48:721-731

44. Cacciuttolo MA, Trinh L, Lumpkin JA, Rao G: Hyperoxia induces DNA damage in mammalian cells. Free Radic Biol Med 1993, 14:267-276.

45. Waxman AB, Kolliputi N: IL-6 protects against hyperoxia-induced mitochondrial damage via $\mathrm{Bcl}-2$-induced Bak interactions with mitofusions. Am J Respir Cell Mol Biol 2009, 41:385-396.

46. Schwarzwald CC, Bonagura JD, Muir WW: The cardiovascular system. In Equine Anesthesia Monitoring and Emergency Therapy.. 2 edition. Edited by: Muir WW, Hubbell JAE. St. Louis: Saunders Elsevier; 2009:37-100.

doi:10.1186/1746-6148-7-23

Cite this article as: Hubbell et al.: Effect of $50 \%$ and maximal inspired oxygen concentrations on respiratory variables in isofluraneanesthetized horses. BMC Veterinary Research 2011 7:23.

\section{Submit your next manuscript to BioMed Central} and take full advantage of:

- Convenient online submission

- Thorough peer review

- No space constraints or color figure charges

- Immediate publication on acceptance

- Inclusion in PubMed, CAS, Scopus and Google Scholar

- Research which is freely available for redistribution

Submit your manuscript at www.biomedcentral.com/submit
Biomed Central 